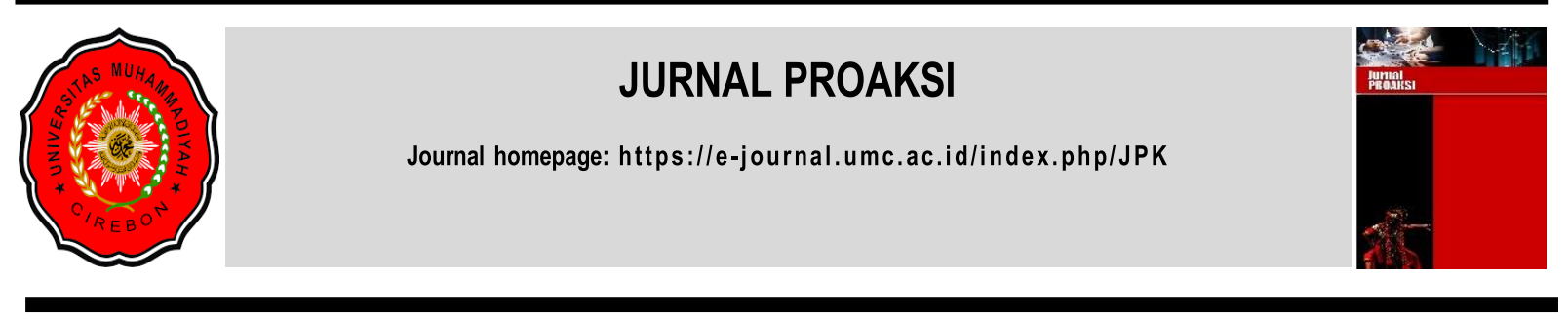

\title{
PENGARUH CR, DER DAN NPM TERHADAP HARGA SAHAM DENGAN DCR SEBAGAI PEMODERASI
}

\author{
Qosim ${ }^{1}$ \\ Sri Trisnaningsih ${ }^{2 *}$ \\ ${ }^{1}$ Magister Akuntansi, Fakultas Ekonomi dan Bisnis, Universitas Pembangunan Nasional Veteran Jawa Timur, \\ Email : qosim19062020014.mak@student.upnjatim.ac.id \\ ${ }^{2}$ Fakultas Ekonomi dan Bisnis, Universitas Pembangunan Nasional Veteran Jawa Timur \\ *Corresponden Author Email: trisnahendrawan@yahoo.co.id
}

\begin{abstract}
Abstrak
Latar belakang penelitian ini dimulai dari banyaknya perolehan proyek oleh BUMN sektor konstruksi namun berbanding terbalik dengan harga saham emiten tersebut. Tujuan penelitian ini adalah untuk mengetahui bagaimana pengaruh current ratio $(C R)$, debt to equity ratio $(D E R)$ dan net profit margin (NPM) terhadap harga saham dengan Debt to Capital Ratio (DCR) sebagai variabel moderasi. Populasi yang digunakan daam penelitian ini adalah seluruh BUMN sektor konstruksi yang ada di Indonesia. Berdasarkan kriteria yang ditentukan, diperoleh sampel sebanyak 8 BUMN sektor konstruksi. Penelitian ini menggunakan data sekunder yaitu berupa Laporan Keuangan. Penelitian ini merupakan penelitian kuantitatif dengan menggunakan metode analisis deskriptifyang dibantu aplikasi smartPLS 3. Berdasarkan hasil penelitian, didapatkan beberapa kesimpulan sebagai berikut: 1) CR tidak berpengaruh terhadap harga saham BUMN sektor konstruksi. 2) DER tidak berpengaruh terhadap harga saham BUMN sektor konstruksi. 3) NPM tidak berpengaruh terhadap harga saham BUMN sektor konstruksi. 4) Struktur modal tidak mampu memperkuat pengaruh CR dan NPM terhadap harga saham BUMN sektor konstruksi. 5) Struktur modal mampu memperkuat pengaruh DER terhadap harga saham.
\end{abstract}

Kata Kunci : CR, DER, NPM, Harga saham dan DCR.

\section{PENDAHULUAN}

Pemerintahan Joko Widodo saat ini fokus dalam pembangunan infrastruktur. Tujuannya adalah untuk meningkatkan kesinambungan dan pertumbuhan ekonomi. Pembangunan ini dirasa sangat penting mengingat dampaknya yang sangat signifikan terhadap peningkatan perekonomian antar wilayah, karena dengan pembangunan ini sama artinya dengan membangun masa depan sebuah peradaban, karena pembangunan infrastruktur dapat berperan sebagai perangsang bergeraknya beragam aktivitas ekonomi (https://economy.okezone.com/, 2018). Hal ini tentunya memberikan pengaruh terhadap Para pelaku usaha di bidang infrastruktur baik BUMN dan swasta yang ikut menikmati kesempatan ini. Hal ini juga merupakan salah satu alasan Indonesia menjadi tujuan investasi negara lain, bahkan lebih besar dari negara-negara ASEAN yang lain.

Namun sebagian pihak menilai bahwa masa depan bisnis konstruksi akan suram karena permasalahan yang berat, yaitu Kontraktor swasta tertekan oleh dominasi BUMN. Sementara BUMN terancam oleh jeratan utang yang telah mereka miliki sebelumnya. Kontraktor swasta yang tertekan oleh dominasi BUMN akhir-akhir ini terlihat nyata, mengutip laporan Gabungan Pelaksana Konstruksi 
Nasional Indonesia (Gapensi), bahwa ada tiga puluh tujuh ribu perusahaan konstruksi swasta yang gulung tikar sebagai akibat banyaknya perolehan proyek oleh BUMN.

Salah satu bentuk dominasi BUMN atas kontraktor swasta adalah dalam proyek pembangunan Bandara Internasional Yogyakarta, Kulonprogo yang diselenggarakan PT Angkasa Pura I. Hanya 10 perusahaan yang diundang lelang dan Semuanya merupakan BUMN. Dalam pembangunan 65 bendungan di seluruh Indonesia, sepanjang 2015-2019, BUMN juga memenangkan seluruh tender. Namun, yang menjadi pertanyaan adalah dengan perolehan kontrak kerja yang sedemikian besar, harga saham BUMN sektor konstruksi justru rendah. Pada akhir tahun 2018, harga saham BUMN konstruksi menurun dua belas prosen. Di sepanjang tahun 2017, nilainya sudah menurun rata-rata tiga belas koma tujuh puluh persen. Keadaan ini berbanding terbalik apabila dilihat dari perolehan proyek oleh BUMN sektor konstruksi.

Current ratio (CR) adalah rasio yang membandingkan harta dengan kewajiban lancer sebuah perusahaan. CR adalah salah satu dari rasio likuiditas yang digunakan untuk menggambarkan sejauh mana kesanggupan suatu entitas dalam mengkover hutang jangka pendeknya memakai harta lancar (Suryana, 2019). Suatu perusahaan dikatakan dalam kondisi prima apabila mampu membayar kewajiban lancarnya, dan juga bisa memberikan peningkatan terhadap nilai jual saham perusahaan sehingga dapat menarik minat investor untuk berinvestasi pada suatu perusahaan tanpa alasan. Hasil penelitian yang dilakukan oleh Suryana (2019), dan Annisa, R \& Chabachib, M (2017) memberikan pernyataan bahwa Current Ratio (CR) tidak memiliki pengaruh terhadap harga Saham. Namun hasil penelitian yang dilakukan oleh Sriwahyuni (2017) dan Priliyastuti (2017) menyatakan bahwa CR berpengaruh terhadap Saham.

Debt to equity ratio (DER) merupakan rasio yang paling banyak dipakai dalam analisa dasar yang bersifat penting. DER memberikan gambaran seberapa besar kemampuan perusahaan untuk memenuhi kewajiban denagn menggunakan ekuitas total yang dimilikinya atau dapat dikatakan besaran perbandingan hutang dengan kekayaan yang dimiliki sendiri (Suryana, 2019). Investor/calon investor akan menganalisis DER untuk memastikan apakah hutang suatu perusahaan besar/ wajar atau tidak. Apabila utang perusahaan wajar, pemilik modal akan memiliki keyakinan untuk menginvestasikan harta yang dimilikinya pada suatu perusahaan. Hasil penelitian yang dilakukan oleh Jenni Suryana (2019), Priliyastuti (2017), dan Sriwahyuni (2017) menyatakan bahwa DER tidak mempengaruhi harga Saham suatu perusahaan. Sedangkan pernyataan bahwa DER berpengaruh terhadap Saham merupakan hasil penelitian yang dilakukan oleh Hutapea (2017).

Net profit margin (NPM) merupakan rasio yang dipakai untuk menggambarkan kapasitas perusahaan dalam mendatangkan laba. Besarnya NPM mengartikan semakin ekonomis operasional suatu perusahaan (Suryana, 2019). Semakin besar NPM, maka perusahaan dapat dikatakan menguntungkan/profitable, sehingga akan dapat meyakinkan investor untuk menanamkan modalnya pada perusahaan tersebut. Penelitian yang dilakukan oleh Hutapea (2017) dan memberikan hasil bahwa NPM tidak berpengaruh terhadap Saham, namun tidak sejalan dengan penelitian yang dilakukan oleh Ligockal dan Stavarek (2018), Kholifah et al. (2018), dan Suryana (2019) yang menyatakan bahwa NPM berpengaruh terhadap Saham.

Penelitian ini bertujuan untuk mengetahui sejauh mana pengaruh CR, DER dan NPM yang di moderasi DCR terhadap harga saham dengan pada BUMN sektor konstruksi periode 2015- 2019. Dengan penelitian akan diketahui apakah harga saham BUMN sektor konstruksi dipengaruhi oleh CR, DER dan NPM dan DCR mampu memperkuat pengaruh ketiga variabel tersebut.

\section{KAJIAN TEORI}

Banyak penelitian yang menggunakan Signaling theory untuk memberi penjelasan tentang pandangan pasar dalam kebijakan deviden suatu entitas (Abdullah, 2002). Signaling theory menyatakan kebijakan deviden sebagai suatu cerminan manajer perusahaan tentang arus kas dimasa yang akan dating suatu perusahaan dan bagaimana reaksi pasar terhadap pandangan tersebut.

Harga yang digunakan pada pasar modal pada suatu periode tertentu yang ditentukan oleh para pelaku pasar modal merupakan pengertian dari Harga saham (Dita, 2017). Berdasarkan pengertian tersebut, Harga saham dibedakan menjadi tiga jenis yaitu:

1. Nilai Nominal (Nilai Pari);

2. Nilai Dasar; dan

3. Nilai Pasar. 
Analisis fundamental merupakan salah satu analisis yang digunakan dari beberapa pendekatan untuk menilai harga saham perusahaan. Cara ini dilakukan dengan mempelajari atau mengamati indicator-indikator yang berkaitan dengan keuangan dan manajemen perusahaan.

Rasio lancar adalah rasio yang dimanfaatkan guna mengukur tinggi rendahnya kapasitas perusahaan dalam menutupi kewajiban jangka pendeknya. (Sriwahyuni, 2017). Stockholder's memiliki harapan besar terhadap perusahaan yang memiliki tingkat rasio lancar yang besar. Besarnya rasio lancar suatu perusahaan mengindikasikan besarnya kesanggupan perusahaan untuk membayar dividen. Dari uraian tersebut dapat dibangun sebuah hipotesis:

\section{$\mathbf{H}_{1}=$ Current Ratio berpengaruh terhadap Harga Saham}

Rasio hutang terhadap modal digunakan untuk mengetahui berapa bagian dari modal perusahaan yang bisa dipakai untuk menjamin pinjaman perusahaan (Priliyastuti, 2017). Debt to equity ratio menggambarkan perimbangan kewajiban dan ekuitas dalam pendanaan perusahaan yang bisa diasumsikan kemampuan modal sendiri perusahaan dalam membayar hutang-hutangnya. Hipotesis yang dapat dibangun berdasarkan pernyataan-pernyataan diatas adalah:

\section{$\mathbf{H}_{2}=$ Debt to Equity Ratio berpengaruh terhadap Harga Saham}

Margin keuntungan bersih merupakan suatu perhitungan untuk melihat kemampuan perusahaan dalam memperoleh keuntungan dari hasil penjualan perusahaan. Perusahaan dikatakan optimal apabila NPM yang dimilikinya di atas dua puluh persen pada rata-rata industry (Dita, 2017). Besarnya Net profit margin suatu perusahaan berarti tepat-gunanya manajemen perusahaan memperhitungkan biaya operasionalnya. Dari penjelasan diatas, dapat dibangun hipotesis sebagai berikut:

\section{$\mathbf{H}_{3}=$ Net Profit Margin berpengaruh terhadap Harga Saham}

Current ratio mengungkapkan kapabilitas perusahaan untuk mencukupi pinjaman jangka pendeknya yang jatuh tempo. Sedangkan debt to capital ratio (DCR) adalah penetapan proporsi long term debt dan modal oleh manajer perusahaan untuk mendanai seluruh kegiatan yang ada didalam perusahaan untuk menghasilkan penjualan. Brigham dan Houston (2011:155) menjelaskan bahwa capital structure yang optimal adalah capital structure yag dapat memberikan peningkatan terhadap harga sahamnya. Dari uraian yang dikemukakan sebelumnya, hipotesis yang dapat dibangun adalah:

\section{$\mathrm{H}_{\mathbf{4}}=$ DCR memperkuat pengaruh CR terhadap saham}

Debt to equity ratio merupakan penggambaran perbandingan dari total hutang dengan total modal perusahaan yang dipakai sebagai sumber dana usaha. Capital structure ialah perimbangan/perbandingan antara total hutang jangka panjang dengan modal sendiri perusahaan. Bagi sebagian perusahaan pendanaan yang bersumber dari pinjaman lebih menguntungkan dari pada pendanaan yang bersumber dari modal sendiri, karena pinjaman akan memberikan bunga. Bunga pinjaman dapat mnegurangi penghasilan kena pajak sehingga mempengaruhi modal perusahaan sesuai dengan komposisi hutang terhadap modal sendiri. Hal ini akan meningkatkan nilai perusahaan sehingga harga sahamnya cenderung meningkat. Berdasarkan penjelasan diatas, dapat ditarik sebuah hipotesis:

\section{$\mathrm{H}_{5}=$ DCR memperkuat pengaruh DER terhadap saham}

Tolok ukur pemegang saham dalam meninvestasikan dananya diketahui dengan banyak cara, salah satunya dapat dilihat melalui laba yang dapat dihasilkan perusahaan pada suatu periode tertentu, tingkat pengembalian dan resiko-resiko yang ditimbulkannya. Informasi tersebut dapat dihitung dengan rasio profitabilitas maupun struktur modal pada perusahaan tersebut. Net Profit Margin menghitung banyaknya laba dari setiap rupiah penjualan setelah dikurangi semua biaya operasional, bunga dan pajak penghasilan. Atau dapat juga dikatakan bahwa NPM menghitung besaran setiap rupiah yang dihasilkan dari kegiatan penjualan perusahaan terhadap laba yang diperolah perusahaan. Besarnya margin yang didapatkan perusahaan menunjukkan bahwa manajemen perusahaan dapat mengatur biaya operasionalnya atau dengan kata lain perusahaan dalam keadaan persaingan yang dapat diperhitungkan. Berdasarkan keterangan-keterangan yang diuraikan, dapat diambil sebuah hipotesis:

\section{$\mathrm{H}_{6}=$ DCR memperkuat pengaruh NPM terhadap saham}

\section{METODE PENELITIAN}

Jenis Penelitian yang dipakai dalam penelitian ini ialah jenis penelitian kuantitatif yaitu cara penelitian yang berdasarkan pada paham pemikiran positif, untuk melakukan penelitian dengan populasi/sampel kategoris dan penggunaan teknik sampling acak. Data yang digunakan dalam 
penelitian ini dikumpulkan dengan teknik dokumentasi yaitu mengumpulkan data laporan keuangan tahunan BUMN Sektor konstruksi yang dipublikasikan secara rutin.

Pengambilan sampel dalam penelitian ini adalah purposive sampling, yaitu teknik penentuan sampel dengan menggunakan kriteria tertentu. Adapun kriteria yang syaratkan dalam penelitian ini adalah:

1. BUMN Sektor konstruksi yang terdapat di Indonesia.

2. BUMN mempublikasikan Laporan keuangan berturut-turut dari tahun 2015 - 2019.

Berdasarkan kriteria yang digunakan diatas, diperoleh sampel yang memenuhi syarat sebanyak 8 BUMN sektor konstruksi. Adapun nama BUMN yang dijadikan sampel pada penelitian ini antara lain:

1. PT Adhi Karya (Persero) Tbk;

2. PT Brantas Abipraya (Persero);

3. PT Hutama Karya (Persero);

4. Perum Pembangunan Perumahan Nasional;

5. PT Pembangunan Perumahan (Persero) Tbk;

6. PT Waskita Karya (Persero) Tbk;

7. PT Wijaya Karya (Persero) Tbk;

8. PT Nindya Karya (Persero).

Variabel dependen yang digunakan dalam penelitian ini yaitu Harga Saham. Menurut Nkuah dan Yusif (2016) Harga Saham bisa diperoleh dengan menggunakan:

\section{Harga Saham $=$ Close Price}

Menurut Gitman dan Zutter $(2015,119)$ Current Ratio didapat dengan membagi aktiva lancar dengan hutang lancar seperti berikut:

\section{Current Ratio $($ CR $)=$ Aktiva lancar / Hutang lancar}

Menurut Gitman dan Zutter $(2015,126)$ Debt to Equity Ratio diperoleh dari total hutang dibagi dengan total equitas, perhitungannya adalah :

\section{Debt to Equity Ratio $($ DER $)=$ Total Hutang/Total equitas}

Menurut Gitman dan Zutter $(2015,131)$ Net Profit Margin dihitung dengan membandingkan laba bersih dengan penjualan bersih, atau :

\section{Net Profit Margin $($ NPM) $=$ Net Profit/ Net Sales}

Penelitian ini menggunakan Moderating variable Rasio utang terhadap modal (Debt-to-Capital Ratio). DCR yaitu salah satu rasio utang yang berpusat pada Hutang yang merupakan unsur dasar dari total modal perusahaan. Hutang meliputi keseluruhan kewajiban baik jangka pendek maupun panjang. Sedangkan modal termasuk pinjaman perusahaan dan modal yang berasal dari pemegang saham.

Variabel DCR dihitung dengan membagi total hutang dengan total hutang yang dijumlahkan dengan total ekuitas. Dikutip dari (cerdasco.com, 2019), rumus yang digunakan untuk mengukur Debt to Capital Ratio adalah:

\section{DCR = Total utang saat ini / (Total utang + Total ekuitas $)$}

\section{HASIL DAN PEMBAHASAN \\ Outer Model atau Model Pengukuran}

Evaluasi yang dilakukan untuk menilai validitas dan reabilitas model disebut Outer model atau yang biasa dinamakan Model Pengukuran. Convergent validitiy adalah merupakan salah satu cara mengevaluasi outer model yang memiliki indikator refleksif. Untuk melakukan Uji validitas konvergen adalah menggunakan aplikasi smart PLS denga melihat nilai loading factor untuk setiap konstruk, yang mana loading factor yang diterima adalah lebih besar dari 0,7. Untuk penilaian, nilai diatas 0,5 masih dapat diterima dan nilai dibawah 0,5 tidak dapat diterima dan harus dikeluarkan dari model. Nilai Average Variance Extracted (AVE) juga harus lebih besar dari 0,5 untuk dapat diterima. 
Uji validitas diskriminan dikaitkan dengan prinsip bahwa untuk mengukur model yang berbeda seharusnya tidak berkorelasi dengan tinggi. Caranya adalah dengan melihat nilai cross loading pada setiap variabel yang digunakan harus lebih dari 0,50. Average Variance Extracted (AVE) adalah cara lain yang bisa dipakai untuk mengukur validitas diskriminan. Dianjurkan nilai AVE lebih besar 0,50. Pengukuran untuk uji reliabilitas data dalam penelitian ini menggunakan cronbach's alpha maupun composite reliability. Reliabilitas dapat dikatakan baik dalam sebuah penelitian apabila nilai composite reability $>0,7$. Dalam penelitian ini diperoleh data seperti ditunjukkan tabel berikut :

Tabel 1. Hasil Pengukuran Outer Model

\begin{tabular}{cccccc}
\hline Variabel & Nilai Loading Factor & AVE & $\begin{array}{c}\text { Cronbach's } \\
\text { Alpha }\end{array}$ & $\begin{array}{c}\text { Composite } \\
\text { Reliability }\end{array}$ & Hasil \\
\hline $\mathrm{X}_{1}$ & 1,00 & 1,00 & 1,00 & 1,00 & Valid \\
$\mathrm{X}_{2}$ & 1,00 & 1,00 & 1,00 & 1,00 & Valid \\
$\mathrm{X}_{3}$ & 1,00 & 1,00 & 1,00 & 1,00 & Valid \\
$\mathrm{Z}$ & 1,00 & 1,00 & 1,00 & 1,00 & Valid \\
$\mathrm{Y}$ & 1,00 & 1,00 & 1,00 & 1,00 & Valid \\
$\mathrm{X}_{1} * \mathrm{Z}$ & 1,39 & 1,00 & 1,00 & 1,00 & Valid \\
$\mathrm{X}_{2} * \mathrm{Z}$ & 1,29 & 1,00 & 1,00 & 1,00 & Valid \\
$\mathrm{X} 3 * \mathrm{Z}$ & 1,39 & 1,00 & 1,00 & 1,00 & Valid \\
\hline
\end{tabular}

Sumber: Data diolah peneliti, 2021

\section{Inner Model (Model Struktural)}

Pengujian semua variabel potensial dihubungkan satu dengan yang lain dengan didasarkan pada teori entitas disebut juga dengan Inner model. Untuk pengukurannya dengan PLS adalah dilihat dari nilai R-Squaresnya. Hal ini untuk memperkuat prediksi model structural dari setiap variabel potensial. Apabila nilai R-Squares 0.75, maka dapat dikatakan bahwa model kuat. Jika 0.50 maka model dikatakan moderate dan jika 0.25 maka diasumsikan bahwa model lemah. Dalam penelitian ini diperolah pngukuran R-square seperti terlihat dalam tabel berikut :

Tabel 2. Nilai R-square

\begin{tabular}{lc}
\hline \multicolumn{1}{c}{ Variabel } & R-square \\
\hline Harga saham & 0,355 \\
\hline Sumber: Data diolah peneliti, 2021
\end{tabular}

Tabel Nilai R-squre memperlihatkan nilai R-square pada variabel laten yaitu Harga saham adalah sebesar 0,355, yang dapat ditafsirkan bahwa model mampu mendefinisikan harga saham sebesar 35,5\%. Pernyataan tersebut menyiratkan Harga saham dalam penelitian ini dipengaruhi oleh variabel independen (CR, DER dan NPM) sebesar 35,5\% dan 64,5\% sisanya adalah dipengaruhi oleh variabel lain yang tidak terdapat pada penelitian ini.

\section{Uji Hipotesis}

Pengujian hipotesis dilakukan untuk melakukan pembuktian akan kebenaran hipotesis penelitian atau dugaan sementara. Hubungan antar variabel diukur dengan melihat path coefficients dan nilai signifikansinya. Pengujian hipotesis dalam penelitian ini dilihat dari path coefficients dan nilai p-values untuk mengukur tingkat signifikansi dengan nilai alpha sebesar lima persen. Uji hipotesis dilakukan terhadap sampel yaitu BUMN sektor konstruksi yang mempublikasikan laporan keuangannya dari tahun 2015 - 2019 berturut-turut. Asumsinya, apabila nilai t statistik > 1,96 maka dapat disimpulkan bahwa terdapat pengaruh signifikan antar variabel tersebut dan jika sebaliknya maka tidak terdapat pengaruh antar variabel tersebut.

Tabel 3. Hasil Output Path Coefficients

\begin{tabular}{clcccl}
\hline Hipotesis & \multicolumn{1}{c}{ Path } & T statistics & P Value & Keputusan & Kesimpulan \\
\hline H1 & CR $\rightarrow$ HS & 0,269 & 0,788 & Ditolak & Tidak Terdapat Pengaruh \\
H2 & DER $\rightarrow$ HS & 1,763 & 0,079 & Ditolak & Tidak Terdapat Pengaruh \\
H3 & NPM $\rightarrow$ HS & 0,259 & 0,796 & Ditolak & Tidak Terdapat Pengaruh \\
H4 & DCR $\rightarrow$ CR $\rightarrow$ HS & 0,626 & 0,532 & Ditolak & Tidak Terdapat Pengaruh \\
H5 & DCR $\rightarrow$ DER $\rightarrow$ HS & 2,171 & 0,030 & Diterima & Terdapat Pengaruh \\
H6 & DCR $\rightarrow$ NPM $\rightarrow$ HS & 1,049 & 0,295 & Ditolak & Tidak Terdapat Pengaruh \\
\hline
\end{tabular}

Sumber: Data diolah peneliti, 2021 


\section{Pengaruh CR Terhadap Saham}

Berdasar tabel uji hipotesis diatas kita dapat melihat bahwa nilai t statistik CR terhadap Harga Saham adalah 0,269. Ini menandakan bahwa nilai t statistik $<1,96$ atau p value $>\alpha(0,269<1,96$ atau $0,788>0,05)$. Maka dapat disimpulan bahwa CR tidak memiliki pengaruh terhadap Saham atau dapat dikatankan bahwa hipotesis 1 ditolak.

CR adalah salah satu analisis rasio likuiditas yang mana para kreditor melakukan pengukuran operasional perusahaan dengan cara melihat aktiva lancar perusahaan apakah akan dapat memenuhi kewajiban lancarnya saat kewajiban tersebut segera ditagih. Semakin besar nilai CR maka kemampuan perusahaan untuk membayar hutang-hutangnya juga semakin besar. Informasi tersebut menjadi bahan pertimbangan bagi kreditor untuk memberikan pinjaman bagi perusahaan. Bagi sebagian investor CR tidak memiliki peranan dalam pemberian kredit karena investor terkadang hanya melihat kegiatan usaha perusahaan tanpa melihat likuiditasnya. Dalam penelitian ini memperlihatkan bahwa variabel CR tidak digunakan oleh para investor sebagai pertimbangan dalam melakukan investasi pada suatu perusahaan.

Besar kecilnya kemampuan BUMN sektor konstruksi dalam memenuhi kewajiban jangka pendeknya tidak dapat dijadikan sebagai alat ukur untuk melihat apakah emiten tersebut memiliki kinerja yang baik atau tidak, hal ini disebabkan besar kecilnya rasio likuditas BUMN sektor konstruksi tidak memiliki dampak terhadap harga saham emiten tersebut. sehingga hanya dengan melihat factor fundamental saja tidak dapat dijadikan pertimbangan bagi investor untuk menanamkan sahamnya.

Hal yang sama ditunjukkan penelitian yang dilakukan oleh Suryana (2019), dan Annisa, R \& Chabachib, M (2017) dimana Current Ratio (CR) tidak memiliki pengaruh terhadap Saham. Penelitian lain menunjukkan hal sebaliknya seperti penelitian terdahulu yang dilakukan oleh Sriwahyuni (2017) dan Priliyastuti (2017).

\section{Pengaruh DER terhadap Saham}

Melihat tabel uji hipotesis diatas dapat diketahui bahwa nilai t statistik antara DER dengan harga saham adalah 1,763 yang berarti nilai t statistiknya $<1,96$ atau $p$ value $>\alpha(1,763<1,96$ atau $0,079>0,05)$. Hal ini dapat diartikan bahwa harga saham tidak dipengaruhi oleh DER dan dapat disimpulkan bahwa hipotesis 2 ditolak.

Analisis terkait pengaruh DER terhadap harga saham dalam penelitian ini menyatakan bahwa DER memiliki pengaruh terhadap harga saham tidak teruji. Hal ini menjelaskan bahwa manajemen perusahaan tidak memanfaatkan kesempatan yang ada untuk berusaha menurunkan beban pajak perusahaan yang seharusnya dapat diperoleh dari beban bunga yang dibayar dari pembiayaan perusahaan yang berasal dari hutang. Hutang bukan merupakan jalan satu-satunya untuk keperluan pengurangan beban pajak, tapi untuk membiayai kegiatan operasional perusahaan. Pada sampel yang digunakan dalam penelitian ini, besarnya hutang perusahaan tidak sepenuhnya digunakan untuk membiayai kegiatan operasional perusahaan namun sebagian besar digunakan untuk menutup pinjaman yang telah jatuh tempo.

Besar kecilnya kemampuan BUMN sektor konstruksi dalam menutupi hutang-hutangnya (baik jangka pendek, menengah maupun jangka panjang) tidak memiliki keterkaitan dan dampak dalam menentukan harga saham emiten tersebut. Melihat besar dan kecilnya DER tidak dapat dijadikan tolak ukur atau menggambarkan BUMN sektor konstruksi memiliki kinerja yang baik atau tidak. Sehingga bagi investor, diperlukan berbagai informasi yang tidak hanya bersumber dari informasi keuangan saja dalam menentukan kebijakan sebelum menanamkan sahamnya pada emiten tersebut. Dalam kacamata investor, perusahaan yang memiliki tingkat DER yang tinggi akan menimbulkan konsekuensi yaitu resiko yang lebih besar jika suatu saat perusahaan mengalami krisis keuangan.

Penelitian sejalan dengan penelitian sebelumnya yang dilakukan oleh Suryana (2019), Priliyastuti (2017), dan Sriwahyuni (2017) yang hasilnya DER tidak berpengaruh terhadap harga saham dan berbanding terbalik dengan penelitian sebelumnya yang dilakukan oleh Hutapea (2017) yang hasilnya DER berpengaruh terhadap harga saham.

\section{Pengaruh NPM terhadap Saham}

Tabel uji hipotesis diatas menyatakan bahwa nilai t statistik NPM terhadap harga saham adalah 0,259 . Hasil tersebut menunjukkan nilai $t$ statistik $<1,96$ atau $p$ value $>\alpha(0,259<1,96$ atau $0,796>$ 0,05). Hasil ini dapat juga diartikan bahwa NPM tidak berpengaruh terhadap harga saham. Sehingga hipotesis 3 ditolak. 
Berdasarkan hasil analisis terkait pengaruh NPM terhadap Saham, maka hipotesis yang dibangun sebelumnya yaitu NPM berpengaruh terhadap harga saham ternyata tidak teruji. Hal ini memberi gambaran seberapa tepat strategi perusahaan dalam mengelola kegiatan penjualan untuk mendapatkan keuntungan. Semakin besar nilai NPM semakin tepat strategi perusahaan tersebut dalam mendapatkan laba dari kegiatan penjualan. Atau dapat dikatakan bahwa perusahaan mampu menekan biaya operasionalnya dengan cara yang tepat dan begitu juga sebaliknya. NPM yang rendah dapat menyebabkan investor tidak berminat untuk menginvestasikan dananya pada suatu perusahaan.

Nilai dari suatu entitas bergantung pada laba atau keuntungan yang dihasilkan oleh aktivaaktivanya (Brigham dan Houston, 2006:70). Unsur aktiva yang merupakan persamaan dari kewajiban ditambah ekuitas ini harus telaah kembali oleh investor. Bisa saja laba yang diperoleh perusahaan tinggi, namun laba tersebut lebih digunakan untuk membayar kewajiban dari pada dibagikan kepada pemegang saham. Begitu juga dengan BUMN sektor konstruksi, hal ini karena besarnya keuntungan atau laba yang dihasilkan oleh emiten tersebut belum bisa menjadi salah satu faktor yang digunakan dalam menentukan basar kecilnya harga saham. Sehingga belum tentu besarnya laba yang dihasilkan emiten tersebut mampu meningkatkan harga sahamnya dan begitu pula sebaliknya kecilnya laba yang dihasilkan tidak membuat harga saham emiten tersebut menjadi turun. Pertimbangan-pertimbangan tersebut menjadikan investor berpikir tidak adanya garansi pengembalian dana yang diinvestasikan kedalam saham yang akan dibeli karena laba yang dihasilkan oleh perusahaan lebih digunakan untuk menutupi hutang-hutangnya.

Penelitian ini memperoleh hasil bahwa NPM tidak memiliki pengaruh terhadap harga saham, hal ini selaras dengan penelitian terdahulu yang dilakukan oleh Hutapea (2017) dannamun penelitian yang dilakukan oleh Marie Ligockal (2018), Kholifah (2018), dan Suryana (2019) yang menyatakan hasil yang berbeda yaitu NPM memiliki pengaruh terhadap harga saham.

\section{DCR Memoderasi Pengaruh CR Terhadap Saham}

Berdasarkan pada tabel uji hipotesis dapat disimpulkan bahwa variabel DCR tidak mampu memperkuat hubungan variabel CR dengan harga saham, hal ini dilihat dari nilai t statistik $<1,96$ atau $\mathrm{p}$ value $>0,05(0,626<1,96$ atau 0,532 >0,05), sehingga dapat diasumsikan bahwa hipotesis 4 ditolak.

Berdasarkan hasil analisis terkait DCR memoderasi pengaruh CR terhadap Saham, maka hipotesis yang dibuat sebelumnya bahwa DCR mampu memperkuat pengaruh CR terhadap harga saham tidak tebukti. Sehingga dikatakan bahwa Struktur Modal yang diproksikan dengan DCR tidak bisa memperkuat pengaruh CR terhadap harga saham, demikian juga sebaliknya DCR tidak bisa membuat harga saham turun pada saat CR rendah.

Besley \& Brigham (2008) dalam satu tulisan mengatakan bahwa Teory signal merupakan sebuah strategi yang dipakai oleh manajemen perusahaan untuk memberikan petunjuk kepada calon investor dalam melihat masa depan keuangan suatu perusahaan. Dengan demikian pihak manajemen akan memberikan berita-berita positif mengenai struktur modal perusahaan yang dapat dijadikan sebagai bahan pertimbangan dalam menentukan harga saham perusahaan guna menarik investor.

Dalam BUMN sektor konstruksi, proporsi perimbangan kewajiban terhadap modal keseluruhan perusahaan tidak mampu memberikan jaminan bahwa kewajiban perusahaan dapat terpenuhi. Meskipun kewajiban jangka pendek dapat terpenuhi namun hal ini tidak mempengaruhi penentuan harga saham perusahaan tersebut. Oleh karena itu pada penelitian ini menjelaskan bahwa Struktur modal belum mampu memeberikan penguatan terhadap kemampuan perusahaan dalam menutupi hutang lancarnya.

\section{DCR Memoderasi Pengaruh DER Terhadap Saham}

Berdasarkan tabel diatas maka dapat diambil kesimpulan bahwa variabel DCR dapat memperkuat pengaruh variabel DER terhadap harga saham yang mana dibuktikan dengan nilai $\mathrm{t}$ statistik $>1,96$ atau $\mathrm{p}$ value $<0,05(2,171>1,96$ atau $0,030<0,05)$. Maka hipotesis 5 diterima.

Berdasarkan hasil analisis terkait DCR memoderasi pengaruh DER terhadap Saham, maka hipotesis penelitian yang menyatakan bahwa DCR memperkuat pengaruh DER terhadap Saham teruji. Artinya bahwa Struktur Modal yang diproksikan dengan DCR mampu memperkuat pengaruh variabel DER terhadap harga saham perusahaan, yang artinya DCR dapat menguatkan harga saham pada saat DER naik dan DCR juga dapat memperlemah nilai harga saham disaat DER turun.

Jama'an (2008) mengasumsikan teori sinyal yang menjelaskan tentang bagaimana sebuah perusahaan seharusnya memberikan sinyal positif kepada pemakai informasi keuangan perusahaan, yaitu sinyal yang berupa informasi tentang perusahaan seutuhnya yang mewakili keingintahuan pemilik 
modal. Dengan demikian, Struktur modal dapat memberikan dorongan kepada investor untuk menginvestasikan dana yang dimilikinya pada perusahaan. Penelitian ini memberikan suatu pengetahuan bahwa debt to equity ratio bisa memberikan sinyal kepada investor untuk melakukan investasi dengan dikuatkan oleh debt to capital ratio.

DCR merupakan perimbangan antara kewajiban terhadap modal keseluruhan perusahaan baik modal milik perusahaan sendiri maupun modal pinjaman. Hal ini memberikan sinyal bahwa dalam BUMN sektor konstruksi struktur modal mampu menguatkan kewajiban perusahaan dalam memenuhi kewajibannya. Semakin tinggi struktur modal yang dimiliki maka kemampuan emiten sektor konstruksi dalam memenuhi kewajibannya akan semakin tinggi dan semakin rendah struktur modal perusahaan maka kemampuan emiten tersebut dalam memenuhi kewajibannya semakin terbatas.

Oleh karena struktur modal memiliki peranan dalam mempengaruhi kewajiban emiten konstruksi dalam memenuhi kewajibannya maka dapat berpengaruh juga terhadap penentuan harga saham dari emiten tersebut. semakin tinggi struktur modal yang dimiliki makan harga saham emiten akan meningkat dan begitu juga sebaliknya.

\section{DCR Memoderasi Pengaruh NPM Terhadap Saham}

Dengan memperhatikan tabel diatas, dapat ditarik sebuah kesimpulan bahwa variabel DCR tidak bisa memperkuat pengaruh antara NPM terhadap harga saham sebab t statistik $<1,96$ atau $p$ value $>0,05(1,049<1,96$ atau 0,295 > 0,05). Oleh karena itu, hipotesis 6 dinyatakan ditolak.

Berdasarkan hasil analisis terkait DCR memoderasi pengaruh NPM terhadap Saham, maka jawaban sementara yang menunjukkan bahwa DCR mampu memperkuat pengaruh NPM terhadap harga saham tidak terbukti. Artinya tidak terdapat pengaruh NPM terhadap harga saham yang diperkuat oleh DCR. Dengan demikian, diperoleh hasil penelitian bahwa DCR tidak dapat membuat harga saham turun pada saat NPM rendah dan tidak membuat harga saham naik pada saat NPM tinggi. Karena efisiensi perusahaan dalam mencapai laba melalui pengelolaan penjualannya.

Melewar (2008) mengatakan teori sinyal mengindikasikan bahwa suatu entitas akan menyampaiakan sinyal positif melalui aktivitas dan koneksi. Suatu perusahaan mengambil sinyal-sinyal untuk mengekspose hal-hal yang tertutup untuk para pihak yang berkepentingan termasuk keuntungan yang diperoleh perusahaan.

Besar kecilnya keuntungan yang dididapatkan oleh BUMN sektor konstruksi tidak memiliki peranan terhadap penentuan harga saham emiten tersebut. Struktur modal yang merupakan perimbangan antara kewajiban terhadap modal keseluruhan emiten juga tidak memiliki peranan dalam menentukan harga saham. Hal ini menegaskan bahwa besar kecilnya struktur modal yang dimiliki tidak memberikan efek terhadap harga saham BUMN sektor konstruksi dan struktur modal yang dimiliki BUMN sektor konstruksi tidak dapat memperkuat pengaruh laba yang dihasilkan perusahaan dalam menentukan harga saham.

\section{KESIMPULAN}

Berdasarkan uraian-uraian yang terdapat pada hasil penelitian dan pembahasan, maka dapat diambil kesimpulan bahwa BUMN merupakan Badan Usaha Milik Negara. Dalam pelaksanaan kegiatan usahanya tidak lepas dari campur tangan pemerintah termasuk pemilikan sahamnya. Oleh sebab itu, dengan adanya penelitian ini dapat diambil kesimpulan bahwa CR yang tinggi dalam BUMN sektor konstruksi tidak menjamin tinnginya harga saham emiten tersebut begitu juga sebaliknya. DER yang tinngi dalam BUMN sektor konstruksi tidak bisa memberikan kontribusi dalam peningkatan harga sahamnya demikian juga rendahnya DER tidak bisa menjadi jaminan menurunnya harga saham emiten tersebut. Tinnginya NPM pada BUMN sektor konstruksi tidak memberi dampak meningkatnya harga saham dan rendahnya NPM juga tidak bias menjadi sebab menurunnya harga saham.

DCR tidak mampu memberikan dampak yang besar dalam membatasi kewajiban BUMN dalam memenuhi kewajiban kewajiban lancarnya, hal ini terjadi karena sebagian besar BUMN lebih memilih kewajiban jangka panjang dalam pemenuhan modalnya. Oleh karena itu, besar kecilnya laba yang dihasilkan BUMN menjadi tidak memiliki pengaruh dalam penentuan harga saham karena laba yang dihasilkan sebagian besar akan digunakan untuk memenuhi kewajiban tersebut.

DCR mampu memberikan kontribusi kemampuan perusahaan dalam menanggung kewajibannya dan dapat menentukan tinggi rendahnya harga saham BUMN sektor konstruksi. Hal ini menegaskan bahwa proporsi perimbangan modal terhadap modal keseluruhan BUMN akan berdampak terhadap kewajiban BUMN dalam membayar hutang-hutangnya. 


\section{SARAN}

Saran Praktis:

1. Meskipun BUMN sektor konstruksi merupakan Perusahaan milik negara, namun dalam pelaksanaan kegiatan usahanya seharusnya mampu menjadi Badan Usaha yang profesional dan mampu mengatur sistem keuangannya, sehingga dari faktor fundamental ini mampu memberikan gambaran yang memiliki peranan besar yang dapat dijadikan sebagai tolak ukur investor dalam menentukan kebijakan investasinya.

2. BUMN sektor konstruksi lebih independen dalam pelaksanaan kegiatanya sehingga mampu menjadi alat pemerintah dalam pemerataan pembangunan ekonomi nasional. Sehingga pembangunan ekonomi nasional dapat berjalan sesuai yang sudah direncanakan. Dengan begitu, akan banyak investor yang tertarik dan menjadikan Indonesia sebagai negara tujuan

\section{Saran Teoritis:} investasi dengan hasil yang menjanjikan.

1. Peneliti selanjutnya mencoba untuk menggunakan variabel berbeda yang dapat memoderasi pengaruh rasio keuangan terhadap harga saham BUMN sektor konstruksi yang ada di Indonesia misalkan keadaan politik atau kondisi social.

2. Pemegang saham harus menekankan perlakuan good corporate governance kepada perusahaan agar mendapatkan laporan atas hasil invertasi yang sebenarnya.

\section{REFERENCE}

Abdullah, S. (2002). Free Cash Flow, Agency Theory Dan Signaling Theory: Konsep dan Riset Empiris. Jurnal Akuntansi dan Investasi, 151-170.

Albertha W. Hutapea, I. S. (2017). Pengaruh Return on Assets, Net Profit Margin, Debt to Equity Ratio, dan Total Assets Turnover terhadap Harga Saham Industri Otomotif dan Komponen yang Terdaftar Di Bursa Efek Indonesia. Jurnal EMBA, 541 - 552.

Annisa, R., \& Chabachib, M. (2017). ANALISIS PENGARUH CURRENT RATIO (CR), DEBT TO EQUITY RATIO (DER), RETURN ON ASSETS (ROA) TERHADAP PRICE TO BOOK VALUE (PBV), DENGAN DIVIDEND PAYOUT RATIO SEBAGAI VARIABEL INTERVENING. Diponegoro Journal of Management, 6(1), 188-202.

Besley, Scott., \& Brigham Eugene F. 2008. Essentials of Managerial Finance. USA: South-Western.

Brigham, Eugene F dan Houston. 2006. Fundamental of Financial Management: Dasar-Dasar Manajemen Keuangan. Edisi 10. Jakarta: Salemba Empat.

Brigham, Eugene F dan Joel F. Houson. 2011. Dasar - Dasar Manajemen Keuangan. Alih Bahasa Ali Akbar Yulianto, Buku dua, Edisi Sebelas. Jakarta: Salemba Empat

Dita, N. C. (2017). PENGARUH ECONOMIC VALUE ADDED (EVA), NET PROFIT MARGIN (NPM), RETURN ON EQUITY (ROE), DAN RETURN ON INVESTMENT (ROI) TERHADAP HARGA SAHAM. Jurnal Administrasi Bisnis

Gitman, Lawrence J dan Chad J. Zutter. 2015. Principles of Managerial Finance. 14th Edition. Global Edition. Pearson Education Limited

Jama'an, Jama'an. (2008). PENGARUH MEKANISME CORPORATE GOVERNANCE, DAN KUALITAS KANTOR AKUNTAN PUBLIK TERHADAP INTEGRITAS INFORMASI LAPORAN KEUANGAN (Studi Pada Perusahaan Publik di BEJ). Tesis : Universitas Diponogoro. Semarang

Kholifah, Lilik; Ulfah, Yana; Iskandar, Iskandar. (2018). Analisa pengaruh current ratio dan net profit margin terhadap harga saham di perusahaan transportasi yang terdaftar di bursa efek indonesia. Jurnal Ilmu Akuntansi Mulawarman (JIAM) doi:http://dx.doi.org/10.29264/jiam.v3i2.2628.

Ligocka, Marie dan Stavarek, Daniel (2018). THE RELATIONSHIP BETWEEN FINANCIAL RATIOS AND THE STOCK PRICES OF SELECTED EUROPEAN FOOD COMPANIES LISTED ON STOCK EXCHANGES. Acta Universitatis Agriculturae et Silviculturae Mendelianae Brunensis. Vol. 67 No. 1. Doi: https://doi.org/10.11118/actaun201967010299 
Melewar, T. C. (2008). Facets of Corporate Identity, Communication and Reputation. USA: Taylor \& Francis Group.

Priliyastuti, N. (2017). PENGARUH CURRENT RATIO, DEBT TO ASSET, DEBT TO EQUITY, RETURN ON ASSETS DAN PRICE EARNINGS RATIO TERHADAP HARGA SAHAM. JURNAL BISNIS DAN AKUNTANSI, 320-324.

Sriwahyuni, E. (2017). Pengaruh CR, DER, ROE, TAT, dan EPS terhadap Harga Saham Industri Farmasi di BEI Tahun 2011-2015. JURNAL ONLINE INSAN AKUNTAN, 119-136.

Suryana, J. (2019). PENGARUH CURRENT RATIO (CR), DEBT TO EQUITY RATIO (DER), NET PROFIT MARGIN (NPM) DAN EARNING PER SHARE (EPS) TERHADAP HARGA SAHAM PERUSAHAAN KONSTRUKSI \& BANGUNAN YANG TERDAFTAR DI BURSA EFEK INDONESIA (BEI) PERIODE 2013-2017. JURNAL MANAJEMEN BISNIS DAN KEWIRAUSAHAAN, 19-24 .

cerdasco.com. (2019). Debt to Capital Ratio. https://cerdasco.com/debt-to-capital-ratio/.

https://economy.okezone.com/. (2018, 03 29). https://economy.okezone.com/. Retrieved from https://economy.okezone.com/:

https://economy.okezone.com/read/2018/03/29/320/1879728/dominasi-bumn-di-proyekinfrastruktur-bikin-bisnis-konstruksi-suram

Jurnal.id. (2017). Pengertian dan Faktor yang Memengaruhi Struktur Modal. https://www.jurnal.id/id/blog/2017-pengertian-dan-faktor-yang-memengaruhi-strukturmodal/. 